\title{
STUDIES ON THE RELATION BETWEEN SERUM AND SPINAL FLUID BILIRUBIN DURING EARLY INFANCY ${ }^{1}$
}

\author{
BY MARIDEE NASRALLA, EVA GAWRONSKA, AND DAVID YI-YUNG HSIA
}

(From the Children's Division of the Cook County Hospital; the Genetic Clinic of The Children's Memorial Hospital; and the Department of Pediatrics, Northwestern University School of Medicine, Chicago, Ill.)

(Submitted for publication April 17, 1958; accepted June 26, 1958)

Although bilirubin has been identified in the cerebrospinal fluid of jaundiced patients, the concentration gradient between serum and spinal fluid has not been accurately determined because of the technical difficulties involved in the measurement of minute quantities of bilirubin (1-6). In young infants, the problem is further complicated by having to distinguish between the xanthochromia caused by intracranial hemorrhage from that associated with physiologic hyperbilirubinemia (7). Sharpe and MacLaire (8) and Levinson, Greengard and Lifvendahl (9) noted that 10 to 25 per cent of newborn infants had blood-tinged spinal fluid and assumed that xanthochromia in this age group was the result of hemorrhage. A few years later, Roberts (10) showed by means of the van den Bergh reaction that the pigment was in reality not heme, but bilirubin. Furthermore, he found that the rise and fall of bilirubin during the first few days of life corresponded with the changes in the bilirubin levels in the serum. Using the icteric index, he estimated the concentration of pigment was about 125 times greater in the serum than in the spinal fluid in normal infants, but this ratio is reduced to only 30 times if intracranial hemorrhage should occur. Stempfel and Zetterström (11) have made similar observations on infants with erythroblastosis fetalis. They found that the bilirubin in the spinal fluid in such infants is predominantly indirect-reacting, and showed that a correlation exists between indirect bilirubin and total protein in the spinal fluid.

The blood-spinal fluid barrier for proteins has previously been studied (12-17). Otila (14) found that among premature infants, the spinal fluid protein during the first week of life averaged

\footnotetext{
1 This study was supported in part by grants from the Association for the Aid of Crippled Children, the Spastic Paralysis Research Foundation, and the Chicago Community Trust.
}

$100 \mathrm{mg}$. per cent, and that this did not fall to normal adult levels until about the age of six years. Spiegel-Adolf, Baird, Szekely and Wycis (15) found the mean spinal fluid total protein to be $103.35 \pm 37.14 \mathrm{mg}$. per cent in 14 normal newborns as compared with a value of $28.50 \pm 6.06$ mg. per cent among 18 older children. More recently, Arnhold and Zetterström (17) undertook paper electrophoresis studies of the proteins in serum and spinal fluid during the neonatal period. They found the relative concentrations to be almost constant and felt that the total concentration of protein directly reflected the functional state of the blood-brain barrier and that all fractions penetrated this barrier at the same rate.

In 1956, Abelson and Boggs $(18,19)$ described a method for measuring plasma pigments with a peak at 405 to $415 \mathrm{~m} \mu$ in erythroblastosis fetalis and suggested that the height of this peak may be useful in predicting the severity and prognosis of the disease process. The configuration of these light-absorption curves appear to depend upon the presence of oxyhemoglobins, hematin, and methemalbumin in the serum (20).

The purpose of this present paper is to describe some observations on bilirubin, protein and heme pigments in the spinal fluid of young infants. It is hoped that these may lead to a better understanding of why there is an increased incidence of kernicterus among premature infants and infants with erythroblastosis fetalis.

\section{MATERIALS AND METHODS}

A total of 100 newborn infants delivered at the Cook County Hospital were studied. These included: 1) 34 normal full-term infants weighing five lbs. or more, 2) 49 normal premature infants weighing four and one-half lbs. or less, and 3) 17 infants with erythroblastosis fetalis due either to $\mathrm{Rh}$ or $\mathrm{ABO}$ incompatibility, who were studied prior to exchange transfusion. A small group of older children and adults with jaundice were similarly 
studied and formed a control group. A capillary blood sample was taken in each infant for the determination of serum bilirubin. At the same time, a single lumbar puncture was performed and about 1 to $2 \mathrm{ml}$. of spinal fluid was withdrawn. The spinal fluid was examined microscopically and failed to show more than five red blood cells per cubic millimeter in any instance.

All of the readings were carried out in a Beckmann DU spectrophotometer. Bilirubin in the serum was determined by a modification of the micro method described by Hsia, Hsia and Gellis (21). The serum was diluted 1:10. In cuvette A (blank), $0.5 \mathrm{ml}$. of the diluted serum was mixed with $0.1 \mathrm{ml}$. of diazo blank and $0.6 \mathrm{ml}$. of methanol. In cuvette B (sample), $0.5 \mathrm{ml}$. of the diluted serum was mixed with $0.1 \mathrm{ml}$. of diazo reagent and $0.6 \mathrm{ml}$. of methanol. Both cuvettes were allowed to stand for 30 minutes and read at $540 \mathrm{~m} \mu$. The optical densities (O.D.) were compared with those of a standard curve prepared by dissolving bilirubin (Pfanstiel) in chloroform and treated with diazo reagent in the same manner.

Bilirubin in the spinal fluid was determined by two methods: $a$ ) Thirty-five hundredths $\mathrm{ml}$. of spinal fluid was placed in a cuvette and read against a chloroform blank at $453 \mathrm{~m} \mu$. The O.D. was compared with those of a standard curve prepared by dissolving bilirubin in chloroform and read at the same wave lengths. b) The spinal fluid was either diluted $1: 2$ or used undiluted. In cuvette A (blank), $0.5 \mathrm{ml}$. of spinal fluid was mixed with $0.1 \mathrm{ml}$. of diazo blank and $0.6 \mathrm{ml}$. of methanol. In cuvette B (sample), $0.5 \mathrm{ml}$. of spinal fluid was mixed with $0.1 \mathrm{ml}$. of diazo reagent and $0.6 \mathrm{ml}$. of methanol. These were allowed to stand for 30 minutes and read at $540 \mathrm{~m} \mu$. The O.D. was compared with those of a standard bilirubin curve prepared by dissolving bilirubin in chloroform and treated with diazo reagent in the same manner. A close correlation was found between the two methods ( $r$ equals +0.96 , d.f. equals 94 , $p$ less than 0.01).

Since bilirubin during the newborn period is almost always indirect-reacting (22), no attempt was made to measure the "one minute" or "direct" form in the serum. The relation between the concentration of bilirubin in the serum and spinal fluid was expressed in the form of a ratio $(\mathrm{SB} / \mathrm{SFB})$.

The heme pigment was analyzed in the following manner : $0.35 \mathrm{ml}$. of spinal fluid was placed in a cuvette and read at $400,410,420,430,440,450$ and $460 \mathrm{~m} \mu$. The O.D. at $410 \mathrm{~m} \mu$ was arbitrarily selected to represent the concentration of the heme pigment. No attempt was made to correct for bilirubin.

The total protein in the spinal fluid was determined by

TABLE I

Summary of laboratory findings in newborn infants and older controls

\begin{tabular}{|c|c|c|c|c|}
\hline & $\begin{array}{l}\text { Premature } \\
\text { (4.5 lbs. or less) } \\
\text { infants }\end{array}$ & $\begin{array}{l}\text { Full term } \\
\text { (5 lbs. or more) } \\
\text { infants }\end{array}$ & $\begin{array}{l}\text { Infants with } \\
\text { erythro- } \\
\text { blastosis } \\
\text { fetalis }\end{array}$ & $\begin{array}{c}\text { Older } \\
\text { controls }\end{array}$ \\
\hline \multicolumn{5}{|l|}{ Serum bilirubin } \\
\hline $\begin{array}{l}\text { No. studied } \\
\text { Mean (mg. \%) } \\
\text { S.D. } \\
\text { Range }\end{array}$ & $\begin{array}{c}49 \\
13.7 \\
+7.7 \\
2.0-44.2\end{array}$ & $\begin{array}{c}34 \\
6.7 \\
+\quad 4.0 \\
2.1-16.8\end{array}$ & $\begin{array}{c}17 \\
15.9 \\
+\quad 6.4 \\
4.0-27.4\end{array}$ & $\begin{array}{c}17 \\
12.7 \\
+\frac{1}{12.8} \\
2.1-55.6\end{array}$ \\
\hline \multicolumn{5}{|l|}{ CSF bilirubin } \\
\hline $\begin{array}{l}\text { No. studied } \\
\text { Mean (mg. \%) } \\
\text { S.D. } \\
\text { Range }\end{array}$ & $\begin{array}{r}49 \\
0.61 \\
+0.15 \\
0-1.40\end{array}$ & $\begin{array}{c}34 \\
\quad 0.24 \\
\pm \quad 0.098 \\
0.06-0.49\end{array}$ & $\begin{array}{c}17 \\
0.48 \\
\pm 0.31 \\
0.11-1.29\end{array}$ & $\begin{array}{c}17 \\
0.10 \\
0.06 \\
0.015-0.22\end{array}$ \\
\hline \multicolumn{5}{|l|}{$\mathrm{SB} / \mathrm{CSF}$ ratio } \\
\hline $\begin{array}{l}\text { No. studied } \\
\text { Mean } \\
\text { S.D. } \\
\text { Range }\end{array}$ & $\begin{array}{c}49 \\
22.7 \\
+10.1 \\
6.4-60.0\end{array}$ & $\begin{array}{c}34 \\
33.0 \\
\pm 25.5 \\
8.4-104.9\end{array}$ & $\begin{array}{c}17 \\
44.0 \\
\pm 35.2 \\
8.0-102.0\end{array}$ & $\begin{array}{c}17 \\
152.5 \\
\pm 175.0 \\
28.9-690.0\end{array}$ \\
\hline \multicolumn{5}{|l|}{ Total protein } \\
\hline $\begin{array}{l}\text { No. studied } \\
\text { Mean (mg. \%) } \\
\text { S.D. } \\
\text { Range }\end{array}$ & $\begin{array}{c}49 \\
167.1 \\
\pm 45.0 \\
81.4-259.2\end{array}$ & $\begin{array}{c}34 \\
115.3 \\
\pm 33.9 \\
46.0-194.4\end{array}$ & $\begin{array}{c}17 \\
123.2 \\
\pm 45.2 \\
71.3-256.3\end{array}$ & $\begin{array}{c}17 \\
61.1 \\
+42.2 \\
15.8-216.0\end{array}$ \\
\hline \multicolumn{5}{|l|}{$410 \mathrm{~m} \mu$ peak } \\
\hline $\begin{array}{l}\text { No. studied } \\
\text { Mean (O.D.) } \\
\text { S.D. } \\
\text { Range }\end{array}$ & $\begin{array}{c}44 \\
0.422 \\
\pm 0.21 \\
0.086-0.916\end{array}$ & $\begin{array}{c}31 \\
0.248 \\
+0.125 \\
0.066-0.518\end{array}$ & $\begin{array}{c}15 \\
0.306 \\
\pm 0.152 \\
0.121-0.698\end{array}$ & $\begin{array}{r}11 \\
0.115 \\
\pm \quad 0.055 \\
0.020-0.198\end{array}$ \\
\hline
\end{tabular}




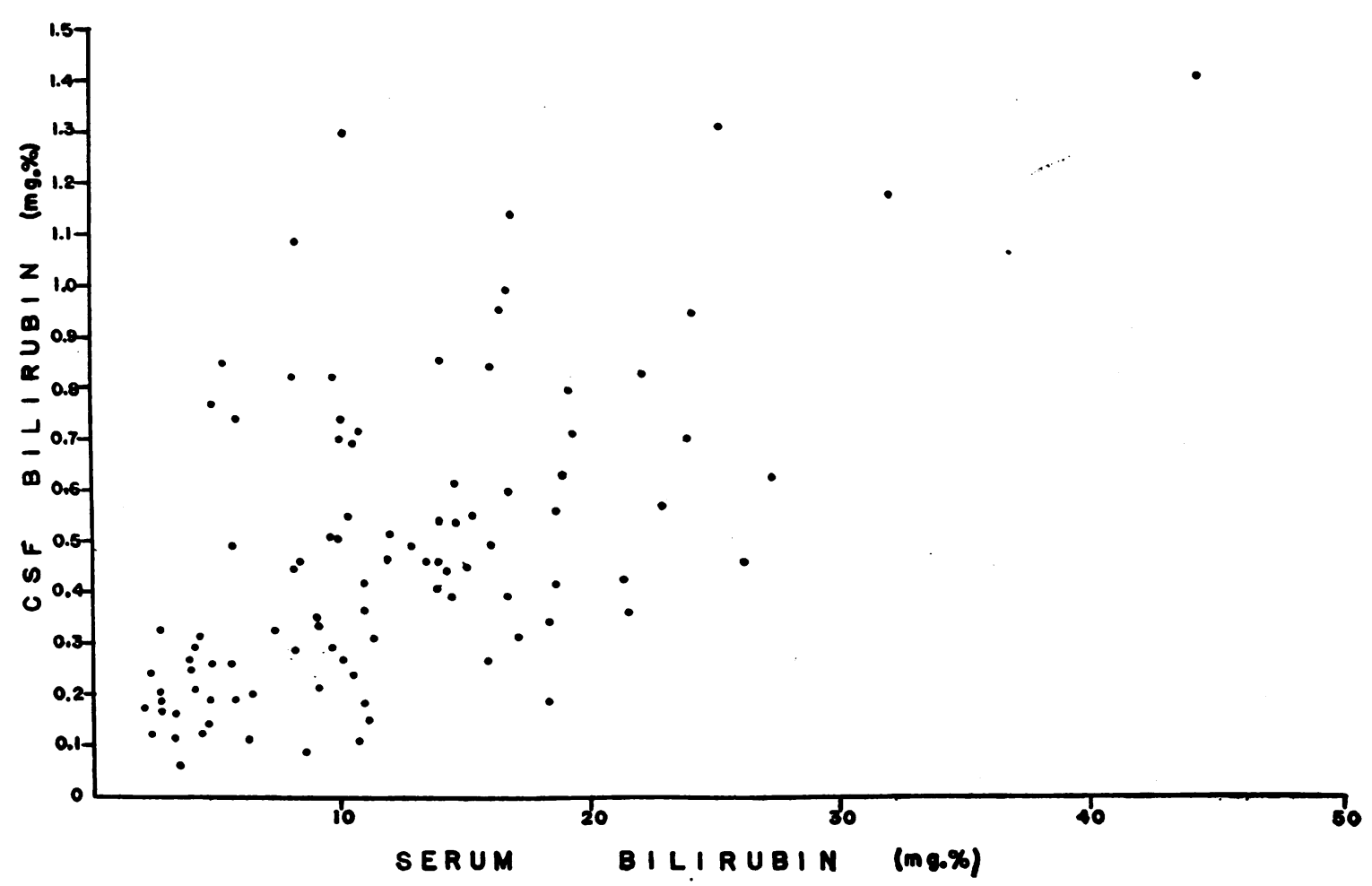

Fig. 1. Serum Bilirubin Versus Spinal Flum Bilirubin (Correlation Coefficient [R] $=+0.58$ )

the method of Waddell (23). The spinal fluid was diluted 1:50 and read at 215 and $225 \mathrm{~m} \mu$. The total protein was calculated as follows:

Total protein $(\mu \mathrm{g} . / \mathrm{ml})=.($ O.D.215 - O.D.2. $) \times 144$.

RESULTS

The means and standard deviations for each group of infants and of the older controls are summarized in Table I.

\section{Relation between serum and spinal fluid bili- rubin}

A scattergram showing the relationship of spinal fluid bilirubin to serum bilirubin for the 100 young infants is given in Figure 1. The correlation is not close, but significant ( $\mathrm{r}$ equals +0.58 , d.f. equals $98, \mathrm{p}$ less than 0.01 ).

It is interesting to note that the $\mathrm{SB} / \mathrm{SFB}$ ratio does not appear to be significantly influenced by the concentration of bilirubin in the serum. The difference between the mean for the 24 infants with serum bilirubin values of $5 \mathrm{mg}$. per cent or less and that of the 11 infants with serum bilirubin values of $20 \mathrm{mg}$. per cent or more is at the 0.05 level.
A. Effect of age. In the present study, it was found that the mean SB/SFB ratio in the controls was $152.5 \pm 175.0$. This agrees closely with previously published data $(4,5)$. In contrast, the $\mathrm{SB} / \mathrm{SFB}$ ratio in the 100 newborn infants was $28.0 \pm 24.9$. The difference is significant ( $t$ equals 2.88, p less than 0.01).

A more detailed analysis of the SB/SFB ratio in the newborn period is tabulated in Table II. In the first two weight groups, the SB/SFB ratio progressively rises as the infant gets older. In the heaviest weight group, the increase can be noted in Groups A and B. Group C consisted of only two cases and the values are not meaningful. The differences between Groups IIA and IIC are significant at the 0.01 level.

B. Effect of birthweight. The SB/SFB ratio was also analyzed in terms of weights at birth in Table II. It can be seen that the SB/SFB ratio rises progressively with an increase in birthweight in each age group. In infants under 48 hours of age, the difference between Groups IA and IIIA is significant at the 0.02 level and that between Groups IIA and IIIA at the 0.05 level. In infants between 49 and 96 hours of age, the difference be- 
TABLE II

Serum bilirubin (SB)/spinal fluid bilirubin (SFB) ratios in 100 newborn infants

\begin{tabular}{|c|c|c|c|c|c|c|c|c|c|c|c|c|}
\hline \multirow[b]{3}{*}{ Age } & \multicolumn{12}{|c|}{ Birthweight } \\
\hline & \multicolumn{3}{|c|}{$\begin{array}{c}\text { Group I } \\
\text { (less than } 4.5 \text { lbs.) }\end{array}$} & \multicolumn{3}{|c|}{$\begin{array}{l}\text { Group II } \\
\text { (5 to } 7 \text { lbs.) }\end{array}$} & \multicolumn{3}{|c|}{$\begin{array}{c}\text { Group III } \\
\text { (more than } 7 \text { lbs.) }\end{array}$} & \multicolumn{3}{|c|}{ Sum } \\
\hline & No. & Mean & S.D. & No. & Mean & S.D. & No. & Mean & S.D. & No. & Mean & S.D. \\
\hline $\begin{array}{l}\text { Group A (0-48 hrs.) } \\
\text { Group B }(49-96 \text { hrs.) } \\
\text { Group C }(97-144 \mathrm{hrs.}) \\
\text { Group D }(144-212 \mathrm{hrs.})\end{array}$ & $\begin{array}{r}10 \\
20 \\
13 \\
6\end{array}$ & $\begin{array}{l}18.8 \\
21.9 \\
26.9 \\
27.3\end{array}$ & $\begin{array}{l} \pm 10.6 \\
\pm 7.5 \\
\pm 11.7 \\
\pm 8.5\end{array}$ & $\begin{array}{r}17 \\
10 \\
4 \\
0\end{array}$ & $\begin{array}{l}22.6 \\
35.6 \\
41.7\end{array}$ & $\begin{array}{l} \pm 16.2 \\
\pm 16.8 \\
\pm 9.0\end{array}$ & $\begin{array}{r}11 \\
7 \\
2 \\
0\end{array}$ & $\begin{array}{l}43.9 \\
48.8 \\
33.3\end{array}$ & $\begin{array}{l} \pm 30.0 \\
\pm 25.9 \\
\pm 10.9\end{array}$ & $\begin{array}{r}38 \\
37 \\
19 \\
6\end{array}$ & $\begin{array}{l}27.7 \\
30.6 \\
30.7 \\
27.3\end{array}$ & $\begin{array}{l} \pm 21.4 \\
\pm 18.7 \\
\pm 12.4 \\
\pm 8.5\end{array}$ \\
\hline Sum & 49 & 22.7 & \pm 10.1 & 31 & 29.2 & \pm 17.5 & 20 & 44.5 & \pm 15.9 & 100 & 28.0 & \pm 24.8 \\
\hline
\end{tabular}

tween Groups IB and IIB is significant at the 0.05 level and that between Groups IB and IIIB at the 0.02 level. In infants between 97 and 144 hours of age, the difference between Groups IC and IIC is significant at the 0.02 level.

In summing the data, the difference between Groups I and II is significant at the 0.05 to 0.10 level, that between Groups II and III at the 0.005 level, and that between Groups I and III at the 0.001 level.

C. Effect of erythroblastosis and kernicterus. The means and standard deviations of the SB/ SFB ratio in 34 normal full-term infants and 17 full-term infants with erythroblastosis fetalis were compared. Although the SB/SFB ratio tends to be higher in the sensitized infants, the difference is not significant ( $\mathrm{t}$ equals $1.10, \mathrm{p}$ equals 0.20 to $0.30)$.
The laboratory data on the three infants who died during the neonatal period are summarized in Table III. Patient 21 was an unsensitized premature who developed marked hyperbilirubinemia in association with sepsis. Opisthotonus developed at 120 hours of age and the diagnosis of kernicterus was confirmed by postmortem examination. Studies performed at 88 hours of age revealed a marked elevation of both serum and spinal fluid bilirubin, but no marked alteration of the SB/SFB ratio. Patient 77 was a full-term infant with erythroblastosis due to anti-E. Clinical signs of kernicterus developed at 130 hours of age and the diagnosis was confirmed by postmortem examination. Studies performed at 121 hours of age showed a high level of bilirubin in the serum, and a slight increase of bilirubin in the

TABLE III

Summary of three patients in present series who died

\begin{tabular}{|c|c|c|c|c|c|c|c|}
\hline Patient & Clinical description & Age & $\underset{\text { bilirubin }}{\text { Serum }}$ & $\underset{\text { bilirubin }}{\text { CSF }}$ & $\underset{\text { ratio }}{\text { SB/SFB }}$ & $\begin{array}{l}\text { Total } \\
\text { protein }\end{array}$ & $\begin{array}{l}410 \mathrm{~m} \mu \\
\text { peak }\end{array}$ \\
\hline \multicolumn{8}{|c|}{ A. Premature infants } \\
\hline $\begin{array}{l}\text { Mean } \\
\text { S.D. }\end{array}$ & & & $\begin{array}{r}13.7 \\
\pm 7.7\end{array}$ & $\begin{array}{r}0.61 \\
\pm 0.15\end{array}$ & $\begin{array}{r}22.7 \\
\pm 10.1\end{array}$ & $\begin{array}{r}167.1 \\
\pm 45.0\end{array}$ & $\begin{array}{l}0.422 \\
\pm 0.21\end{array}$ \\
\hline 21 & $\begin{array}{l}\text { Kernicterus }\left(\mathrm{K}_{\mathrm{I}}\right) \text { developed at } \\
120 \text { hrs.; confirmed postmortem }\end{array}$ & 88 & 32.0 & 1.17 & 30.7 & 233.3 & 0.136 \\
\hline \multicolumn{8}{|c|}{ B. Infants with erythroblastosis } \\
\hline $\begin{array}{l}\text { Mean } \\
\text { S.D. }\end{array}$ & & & $\begin{array}{r}15.9 \\
\pm 6.4\end{array}$ & $\begin{array}{r}0.48 \\
\pm 0.31\end{array}$ & $\begin{array}{r}44.0 \\
\pm 35.2\end{array}$ & $\begin{array}{r}123.2 \\
\pm 45.2\end{array}$ & $\begin{array}{r}0.306 \\
\pm 0.152\end{array}$ \\
\hline 77 & $\begin{array}{l}\mathrm{K}_{\mathrm{I}} \text { developed at } 130 \mathrm{hrs} \text {; } \text { con- } \\
\text { firmed postmortem }\end{array}$ & 121 & 27.4 & 0.63 & 39.1 & 133.3 & 0.350 \\
\hline 58 & $\begin{array}{l}\text { Infant died during } 2 \text { nd exchange } \\
\text { transfusion from } K_{\mathrm{I}} \text { No post- } \\
\text { mortem performed }\end{array}$ & $\begin{array}{l}29 \\
52\end{array}$ & $\begin{array}{l}21.4 \\
23.2\end{array}$ & $\begin{array}{l}0.43 \\
2.69\end{array}$ & $\begin{array}{r}50.9 \\
8.6\end{array}$ & $\begin{array}{r}92.9 \\
283.8\end{array}$ & $\begin{array}{l}0.287 \\
0.195\end{array}$ \\
\hline
\end{tabular}




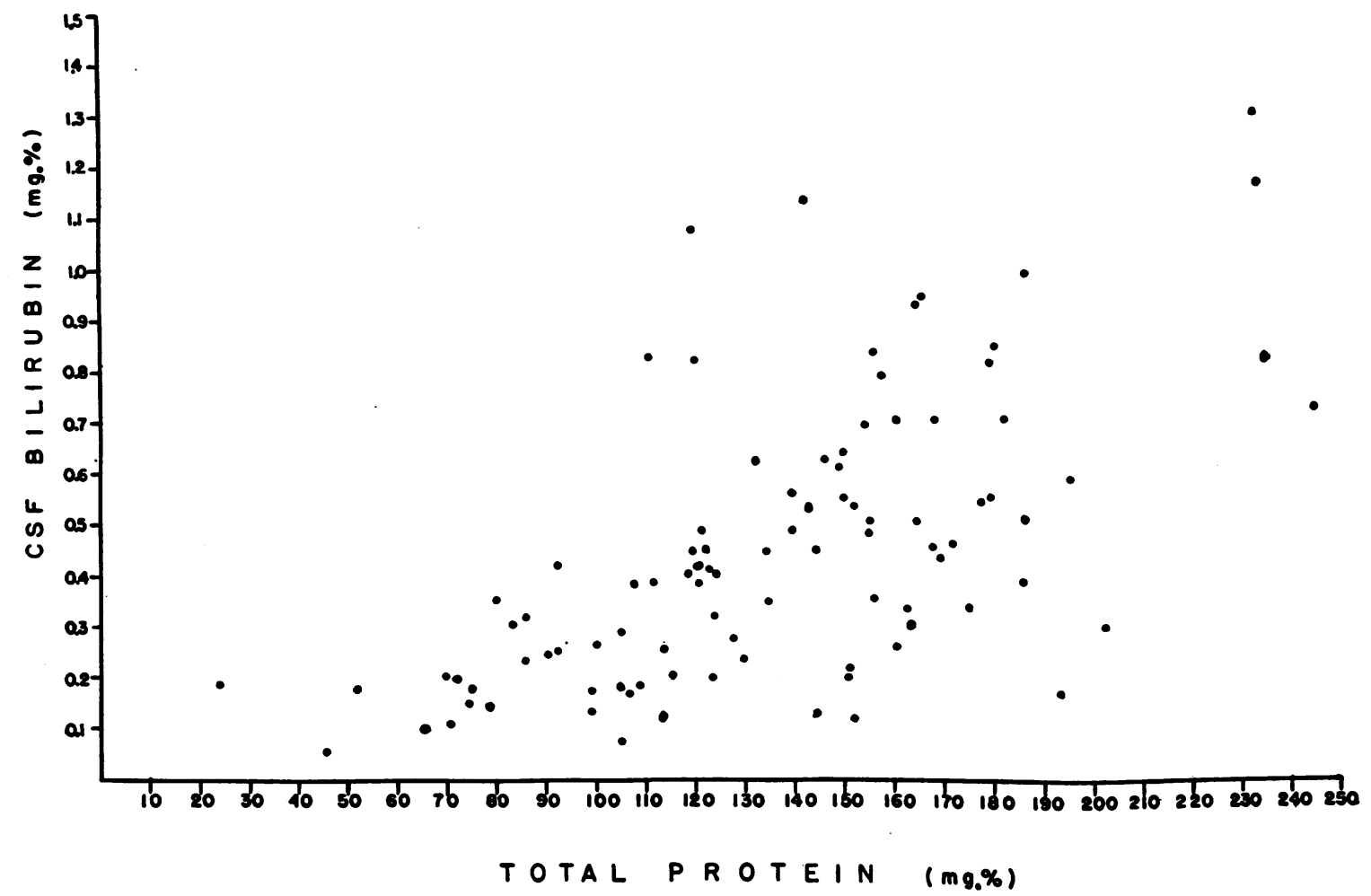

Fig. 2. Spinal Flum Protein Versus Spinal Flum Bilirubin (Correlation Coefficient [R] $=+0.67$ )

spinal fluid. Again, there was no great change in the SB/SFB ratio.

The diagnosis on Patient 58 is uncertain. This full-term infant was found to have erythroblastosis against anti-D and was treated by transfusion both at 30 and 53 hours of age. During the course of the second exchange, the patient developed convulsions and expired shortly afterwards. Postmortem permission was not obtained and it is impossible to know whether kernicterus played a role in his death. Laboratory studies showed a marked rise of both the bilirubin and protein in the. spinal fluid between the first and second lumbar punctures.

\section{Relation between spinal fluid bilirubin and protein}

A scattergram showing the relationship of spinal fluid bilirubin to spinal fluid protein for these same infants is given in Figure 2. The correlation is significant ( $r$ equals +0.67 , d.f. equals $98, p$ less than 0.01).

A. Effect of age. The mean spinal fluid protein in the controls subjects was $61.1 \pm 42.2$. In

TABLE IV

Spinal fluid protein values in 100 newborn infants

\begin{tabular}{|c|c|c|c|c|c|c|c|c|c|c|c|c|}
\hline \multirow[b]{2}{*}{ Age } & \multicolumn{3}{|c|}{$\begin{array}{l}\text { Group I } \\
\text { (less than } 4.5 \text { lbs.) }\end{array}$} & \multicolumn{3}{|c|}{$\begin{array}{l}\text { Group II } \\
\text { (5 to } 7 \text { lbs. })\end{array}$} & \multicolumn{3}{|c|}{$\begin{array}{c}\text { Group III } \\
\text { (more than } 7 \text { lbs.) }\end{array}$} & \multicolumn{3}{|c|}{ Sum } \\
\hline & No. & Mean & S.D. & No. & Mean & S.D. & No. & Mean & S.D. & No. & Mean & S.D. \\
\hline $\begin{array}{l}\text { Group A (0-48 hrs.) } \\
\text { Group B (49-96 hrs.) } \\
\text { Group C }(97-144 \text { hrs. }) \\
\text { Group D }(144-212 \text { hrs. })\end{array}$ & $\begin{array}{r}10 \\
20 \\
13 \\
6\end{array}$ & $\begin{array}{l}\text { mg. } \% \\
166.4 \\
179.8 \\
164.2 \\
144.8\end{array}$ & $\begin{array}{l}m g . \% \\
\pm 47.6 \\
\pm 41.0 \\
\pm 44.8 \\
\pm 24.9\end{array}$ & $\begin{array}{r}17 \\
10 \\
4 \\
0\end{array}$ & $\begin{array}{l}\text { mg. \% } \\
134.3 \\
108.9 \\
129.1\end{array}$ & $\begin{array}{l}m g . \% \\
\pm 41.2 \\
\pm 40.8 \\
\pm 25.0\end{array}$ & $\begin{array}{r}11 \\
7 \\
2 \\
0\end{array}$ & $\begin{array}{l}\text { mg. \% } \\
106.5 \\
106.5 \\
104.8\end{array}$ & $\begin{array}{l}m g . \% \\
\pm 33.9 \\
\pm 25.8 \\
\pm 17.8\end{array}$ & $\begin{array}{r}38 \\
37 \\
19 \\
6\end{array}$ & $\begin{array}{l}m g . \% \\
134.7 \\
146.8 \\
150.6 \\
144.8\end{array}$ & $\begin{array}{l}\text { mg. } \% \\
\pm 46.7 \\
\pm 24.4 \\
\pm 44.4 \\
\pm 24.9\end{array}$ \\
\hline Sum & 49 & 168.6 & \pm 16.2 & 31 & 125.4 & \pm 41.1 & 20 & 106.3 & \pm 30.1 & 100 & 142.7 & \pm 48.3 \\
\hline
\end{tabular}




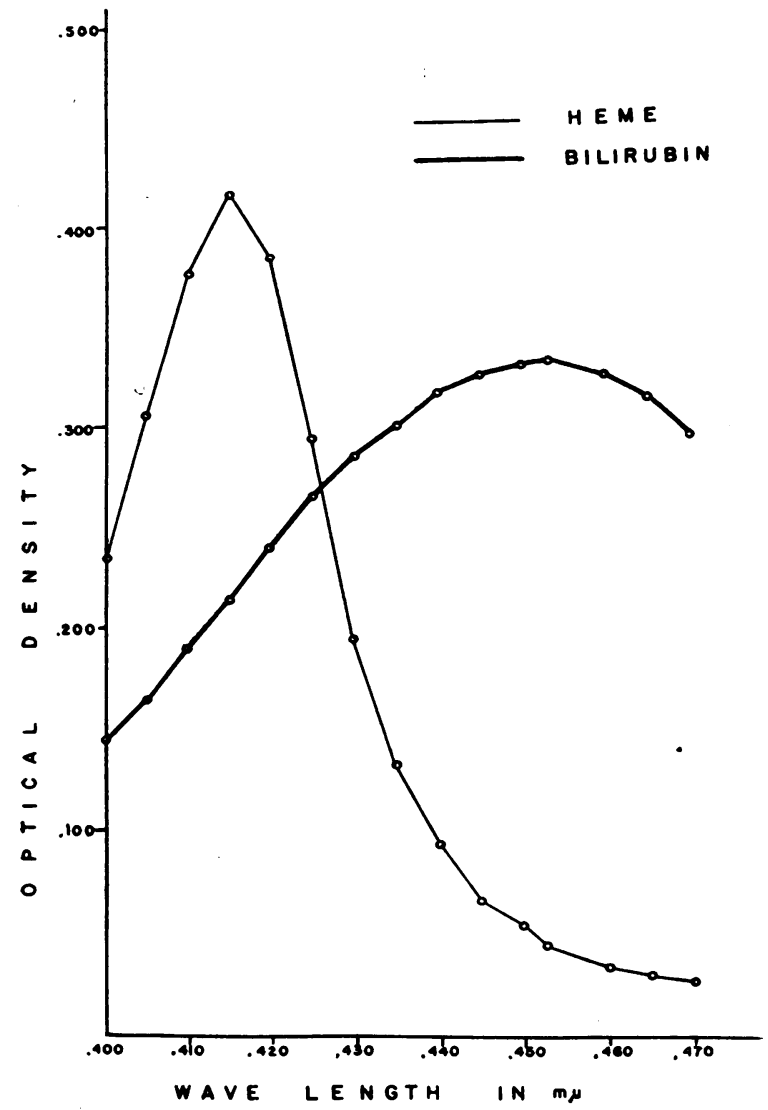

Fig. 3. Spectral Absorption Curves of Bilirubin and HEMOGLOBIN

contrast, the spinal fluid protein in the 100 newborn infants was $142.7 \mathrm{mg}$. per cent. The difference is statistically significant ( $\mathrm{t}$ equals $6.91, \mathrm{p}$ less than 0.001).

A more detailed analysis of the effect of age upon spinal fluid proteins during the neonatal period is tabulated in Table IV. The differences between the groups are not significant.

$B$. Effect of birthweight. The spinal fluid proteins were also analyzed in terms of weight at birth in Table IV. It can be seen that the levels progressively decrease depending upon the weight at birth in each age group. In infants under 48 hours of age, the difference between Groups IA and IIIA is significant at the 0.01 level. In infants between 49 and 96 hours of age, the difference between Groups IB and IIB is significant at the 0.01 level and that between Groups $\mathrm{I}$ and IIIB at the 0.01 level. In the 97 to 144 hour age group, the difference between IC and IIIC is significant at the 0.01 level.
In summing the data, the difference between Groups I and II is significant at the 0.001 level, between Groups II and III at the 0.05 level, and between Groups I and III at the 0.001 level.

C. Effect of erythroblastosis fetalis. The mean and standard deviations of the spinal fluid protein levels in normal full-term infants and full-term infants with erythroblastosis fetalis were compared. The difference is not significant.

\section{Relation between spinal fluid bilirubin and heme pigment at $410 \mathrm{m \mu}$}

The spectral absorption curves of bilirubin (Pfanstiel) and hemoglobin (prepared from red cell hemolysate) are given in Figure 3 . It is apparent that although there is some degree of overlap, the peaks are separate and independent of each other.

A scattergram showing the relationship between spinal fluid bilirubin and heme pigment at $410 \mathrm{~m} \mu$ is shown in Figure 4. A high degree of correlation exists between the two measurements ( $r$ equals +0.86 , d.f. equals 98 , $p$ less than 0.01 ). On the other hand, no relation was found to exist between spinal fluid bilirubin and the spectral absorption curve of the spinal fluids at 420,430 and $440 \mathrm{~m} \mu$.

$A$. Effect of age. Although the $410 \mathrm{~m} \mu$ heme peak was determined in only a few of the control subjects, it would appear that the average values were considerably lower than those seen in newborn infants.

A more detailed analysis of the spinal fluid 410

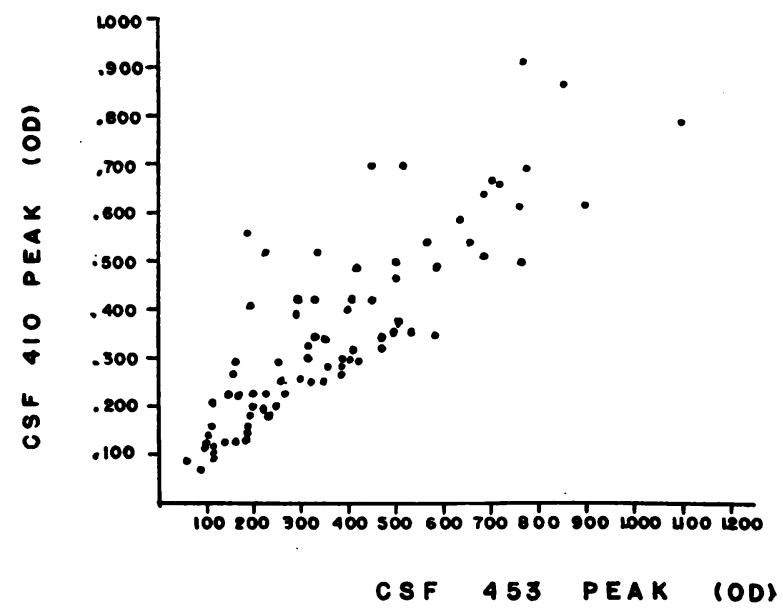

Fig. 4. Spinal Flum 410 m $\mu$ Heme Pear Versus Spinal Fluid Bilirubin 
TABLE V

Spinal fluid 410 mu heme peak in 90 newborn infants

\begin{tabular}{|c|c|c|c|c|c|c|c|c|c|c|c|c|}
\hline \multirow[b]{3}{*}{ Age } & \multicolumn{12}{|c|}{ Birthweight } \\
\hline & \multicolumn{3}{|c|}{$\begin{array}{c}\text { Group I } \\
\text { (less than 4.5 lbs.) }\end{array}$} & \multicolumn{3}{|c|}{$\begin{array}{l}\text { Group II } \\
(5 \text { to } 7 \text { lbs.) }\end{array}$} & \multicolumn{3}{|c|}{$\begin{array}{l}\text { Group III } \\
\text { (more than } 7 \text { lbs.) }\end{array}$} & \multicolumn{3}{|c|}{ Sum } \\
\hline & No. & Mean & S.D. & No. & Mean & S.D. & No. & Mean & S.D. & No. & Mean & S.D. \\
\hline $\begin{array}{l}\text { Group A (0-48 hrs.) } \\
\text { Group B (49-96 hrs.) } \\
\text { Group C (97-144 hrs.) } \\
\text { Group D (144-212 hrs.) }\end{array}$ & $\begin{array}{r}7 \\
18 \\
13 \\
6\end{array}$ & $\begin{array}{l}0.297 \\
0.472 \\
0.462 \\
0.298\end{array}$ & $\begin{array}{l} \pm 0.245 \\
\pm 0.179 \\
\pm 0.237 \\
\pm 0.090\end{array}$ & $\begin{array}{r}14 \\
10 \\
4\end{array}$ & $\begin{array}{l}0.265 \\
0.268 \\
0.263\end{array}$ & $\begin{array}{l} \pm 0.118 \\
\pm 0.167 \\
\pm 0.077\end{array}$ & $\begin{array}{l}9 \\
7 \\
2\end{array}$ & $\begin{array}{l}0.276 \\
0.264 \\
0.254\end{array}$ & $\begin{array}{l} \pm 0.141 \\
\pm 0.158 \\
\pm 0.000\end{array}$ & $\begin{array}{r}30 \\
35 \\
19 \\
6\end{array}$ & $\begin{array}{l}0.276 \\
0.372 \\
0.402 \\
0.298\end{array}$ & $\begin{array}{l} \pm 0.164 \\
\pm 0.202 \\
\pm 0.270 \\
\pm 0.090\end{array}$ \\
\hline Sum & 44 & 0.417 & \pm 0.214 & 28 & 0.266 & \pm 0.134 & 18 & 0.269 & \pm 0.141 & 90 & 0.341 & \pm 0.195 \\
\hline
\end{tabular}

$\mathrm{m} \mu$ heme peak in the newborn period is tabulated in Table V. The differences between the individual groups are not significant. However, it can be seen that the sums of the O.D. at $410 \mathrm{~m} \mu$ rise with age with the differences between Groups $\mathrm{A}$ and $\mathrm{B}$ being significant at the 0.05 to 0.02 level, and that between Groups $\mathrm{A}$ and $\mathrm{C}$ slightly above the 0.05 level.

B. Effect of birthweight. The $410 \mathrm{~m} \mu$ heme peak was also analyzed in terms of weight at birth. It can be seen that the level falls with increases in birthweight. In infants between 49 and 96 hours of age, the difference between Groups IB and IIB is at the 0.005 level and that between Groups IB and IIIB is close to the 0.01 level. There are too few determinations among infants over 97 hours of age for the analysis to be meaningful. However, in comparing the sums, the differences between Groups I and II and Groups I and III are significant at the 0.005 level.

C. Effect of erythroblastosis fetalis. The means and standard deviations of the $410 \mathrm{~m} \mu$ peak in 31 normal full-term infants and 15 infants with erythroblastosis fetalis were compared. Although the levels tend to be slightly higher in the sensitized infants, the difference is not significant ( $t$ equals 1.26 , p 0.20 to 0.30 ).

\section{DISCUSSION}

In the past, reports have appeared showing an alteration in the permeability of the blood-spinal fluid barrier during early infancy to trypan blue (24-26), phosphorus $(27,28)$, potassium (29) and protein $(14,15,17)$. Some workers have attributed these changes to an anatomical disruption of the membrane separating the two compartments due to anoxia and trauma associated with delivery.
Others have suggested that the blood-spinal fluid barrier is functional in nature and passage across the membrane requires the action of transport mechanisms such as enzyme systems (30). A transient immaturity of these systems shortly after birth (31) could lead to a similar change.

In the case of bilirubin, the permeability of the blood-spinal fluid barrier during the newborn period must of necessity depend upon the following factors: 1) the rise and fall of bilirubin levels in the serum, 2) the concentration gradient of bilirubin on both sides of the membrane at any given time, 3) the mechanism by which the pigment is transported across the membrane, 4) the manner by which it is removed from either compartment and 5) the capacity of the bilirubin to become attached not only to circulatory proteins, but also to surrounding tissues. It is apparent that an arbitrary expression such as the SB/SFB ratio is insufficient to account for each of the variables. However, certain concepts are worthy of speculation in the light of the present study.

The data suggest that the relationship between serum to spinal fluid bilirubin depends less upon the concentration of bilirubin in the serum, and more upon such factors as maturity of the infant at birth (as judged by birthweight), and age of the infant at the time the tests were formed. Among the infants with erythroblastosis, the relationship between the serum and spinal fluid bilirubin remains in the same ratio as among normal infants of comparable maturity. However, the high levels of bilirubin in the serum results in parallel increases in spinal fluid bilirubin, sometimes up to $1 \mathrm{mg}$. per cent or higher.

No attempt was made to separate bilirubin from its glucuronide in the serum (32). Klatskin and 
Bungards (33) have shown that both types of bilirubin remain firmly bound to albumin at levels of $\mathrm{pH}$ between 6.0 and 9.0 and separate at levels below 5.0. Since the bilirubin in the serum in this age group is almost always indirect-reacting and all of the infants were clinically free of acidosis, one can assume that bilirubin is firmly bound to protein in the serum and probably enters the spinal fluid as an albumin-bilirubin complex. The positive correlation between spinal fluid bilirubin and total protein would be in agreement with this concept.

The peak at $410 \mathrm{~m} \mu$ for heme and the peak at $453 \mathrm{~m} \mu$ for bilirubin appear to be unrelated to each other because: 1) the spectral absorption curves for bilirubin and hemoglobin are quite distinct as shown in Figure 3,2) in the present study, there was no relation between the spectral absorption curve of the spinal fluids at 420,430 and $440 \mathrm{~m} \mu$ although a close relationship existed between 410 $\mathrm{m} \mu$ and $453 \mathrm{~m} \mu$, and 3) there was close agreement on the values for spinal fluid bilirubin measured by two different techniques. The close correlation between the peaks at $410 \mathrm{~m} \mu$ and $453 \mathrm{~m} \mu$ in spinal fluid leads to some interesting speculation on a possible biochemical interrelation in the extravascular transport of bilirubin and hematin. It is generally agreed that both hematin and bilirubin form serum protein complexes and are apparently transported in that manner. Since the molecular structure of the two compounds is quite similar, it is not unlikely that they occupy similar sites on the protein molecules with which they tend to combine in complex formation. Tuttle (20) has indicated that in the serum, the proteinhematin complexes are relatively more stable than the corresponding bilirubin complexes. This may explain why there is a relatively poor correlation between the peak for heme and bilirubin in the plasma. On the other hand, in the spinal fluid, we find a rather close correlation between the two measurements. Furthermore, a similar relationship between heme and bilirubin seems to exist in infants with erythroblastosis fetalis and in nonsensitized infants. Since Abelson and Boggs (18) have stressed the height of the $410 \mathrm{~m} \mu$ peak in the plasma of infants in the former group, one must assume that the blood-spinal fluid barrier must have in some way blocked the passage of most of the heme. It is conceivable that the al- bumin molecule is "saturated" with both bilirubin and heme groups before passing from the serum into the spinal fluid.

A few years ago, Mollison and Cutbush (34) and Hsia, Allen, Gellis and Diamond (35) reported that kernicterus occurred with greater frequency when the serum bilirubin became markedly elevated in infants with erythroblastosis fetalis. Similarly, the increased incidence of kernicterus among unsensitized prematures (36-42) has been attributed to hyperbilirubinemia on a physiological basis $(22,43)$. Vogel $(44)$ has suggested that kernicterus occurs in such infants because: 1) There is an increased permeability of the blood-brain barrier for bilirubin during early infancy, and 2) the bilirubin is reduced within the brain to mesobilirubin, which gives rise to the cerebral pigmentation in kernicterus. The first of these concepts appears to have been confirmed by the present study. No attempt was made to study the nature of the pigment in the brains of the infants who died. However, in two instances, unusually high spinal fluid bilirubin levels were encountered, and this may have in part been responsible for the development of kernicterus in those infants.

\section{SUM MARY}

Simultaneous samples of serum bilirubin and spinal fluid bilirubin, protein and $410 \mathrm{~m} \mu$ heme peak have been obtained in 100 newborn infants and a number of older controls with jaundice.

A positive correlation coefficient ( $r$ equals + 0.58 ) was obtained between the serum and spinal fluid bilirubin levels. The relation between the serum bilirubin (SB) concentration and spinal fluid bilirubin (SFB) concentration was arbitrarily expressed as the ratio of serum bilirubin/spinal fluid bilirubin. The SB/SFB ratio was the lowest among the smallest and youngest infants. The ratio increased more with weight at birth than with age. The SB/SFB ratio was not significantly altered in infants with erythroblastosis fetalis. Similarly, the concentration of bilirubin in the serum had little effect upon the SB/SFB ratio.

A positive correlation coefficient ( $r$ equals + 0.67 ) was obtained between the spinal fluid bilirubin and total protein. The spinal fluid protein tended to be lower among the more mature infants. 
A positive correlation coefficient ( $r$ equals + 0.86) was obtained between the spinal fluid bilirubin and the $410 \mathrm{~m} \mu$ heme pigment. However, no significant difference existed in the $410 \mathrm{~m} \mu$ heme peak in the spinal fluid of infants with erythroblastosis fetalis and normal full term controls.

The significance of these findings in the pathogenesis of kernicterus was discussed.

\section{ACKNOWLEDGMENT}

The authors wish to express their appreciation to Drs. Irving Abrams, Rowine Brown and Aaron Grossman for their advice and cooperation, and to Dr. Michael Kraus, Dr. Ting-Chien Lee, June Samuels, Winifred Morris and Benetta Lisenbee for their assistance in the blood grouping studies.

\section{REFERENCES}

1. DeCastro, U. Blut-Liquorschranke und Bilirubin bei Ikterus. Dtsch. Arch. klin. Med. 1931, 170, 176.

2. Klein, N., and Szentmihályi, S. Das Bilirubin und die Blut-Liquor-Barriere. Dtsch. Arch. klin. Med. 1932, 173, 234.

3. With, T. K. Bilirubin in urine and other secretions apart from the bile and in the cerebrospinal and eye liquors. Acta physiol. scand. 1945, 10, 355.

4. Amatuzio, D. S., Weber, L. J., and Nesbitt, S. Bilirubin and protein in the cerebrospinal fluid of jaundiced patients with severe liver disease with and without hepatic coma. J. Lab. clin. Med. 1953, 41, 615.

5. Berman, L. B., Lapham, L. W., and Pastore, E. Jaundice and xanthochromia of the spinal fluid. J. Lab. clin. Med. 1954, 44, 273.

6. Barrows, L. J., Hunter, F. T., and Banker, B. Q. The nature and clinical significance of pigments in the cerebrospinal fluid. Brain 1955, 78, 59.

7. Schmorl, C. G. Liquor cerebrospinalis und Ventrikelflüssigkeit. Zbl. allg. Path. path. Anat. 1910, 21, 459.

8. Sharpe, W., and MacLaire, A. S. Observations of intracranial haemorrhage in 400 consecutive newborn babies. J. Obstet. Gynaec. Brit. Emp. 1925, 32, 79.

9. Levinson, A., Greengard, J., and Lifvendahl, R. Cerebrospinal fluid in the new-born. Amer. J. Dis. Child. 1926, 32, 208.

10. Roberts, M. H. Relation of pigment content in serum and spinal fluid of newborn infants. Sth. med. J. (Bgham, Ala.) 1928, 21, 460.

11. Stempfel, R., and Zetterström, R. Concentration of bilirubin in cerebrospinal fluid in hemolytic disease of the newborn. Pediatrics 1955, 16, 184.

12. Samson, K. Der normale Liquor cerebrospinalis im ersten Lebenstrimenon. Z. ges. Neurol. Psychiat. 1930, 128, 494.
13. Samson, K. Die Liquordiagnostik im Kindesalter. Ergebn. inn. Med. Kinderheilk. 1931, 41, 551.

14. Otila, E. Studies on the cerebrospinal fluid in premature infants. Acta paediat. (Uppsala) 1948, 35, Suppl. 8.

15. Spiegel-Adolf, M., Baird, H. W., Szekely, E. G., and Wycis, H. T. Cerebrospinal fluid studies in infant children with cerebral palsy and other neurologic disorders. Pediatrics 1954, 14, 215.

16. Koch, G. Beitrag zur elektrophoretischen Unterschung des Liquor cerebrospinalis im Kindesalter unter besonderer Berücksichtingung der Meningitiden. Z. Kinderheilk. 1956, 77, 563.

17. Arnhold, R. G., and Zetterström, R. Proteins in the cerebrospinal fluid in the newborn. Pediatrics 1958, 21, 279.

18. Abelson, N. M., and Boggs, T. R., Jr. Plasma pigments in erythroblastosis fetalis. I. Spectrophotometric absorption patterns. Pediatrics 1956, 17, 452.

19. Boggs, T. R., Jr., and Abelson, N. M. Plasma pigments in erythroblastosis fetalis. II. The level of heme pigment; an early guide to management of erythroblastosis fetalis. Pediatrics 1956, 17, 461.

20. Tuttle, A. H. Serum pigment studies in newborn infants. I. Erythroblastosis fetalis. J. Dis. Child. 1955, 89, 544.

21. Hsia, D. Y. Y., Hsia, H. H., and Gellis, S. S. A micro-method for serum bilirubin. J. Lab. clin. Med. 1952, 40, 610.

22. Hsia, D. Y. Y., Allen, F. H., Jr., Diamond, L. K., and Gellis, S. S. Serum bilirubin levels in the newborn infant. J. Pediat. 1953, 42, 277.

23. Waddell, W. J. A simple ultraviolet spectrophotometric method for the determination of protein. J. Lab. clin. Med. 1956, 48, 311.

24. Behnsen, G. Uber die Farbstoffspeicherung im Zentralnervensystem der weissen Maus in verschiedenen Alterszuständen. Z. Zellforsch. 1927, 4, 515 .

25. Stern, L., and Peyrot, R. Le fonctionnement de la Barrière hémato-encephalique aux divers Stades de développement chez les diverses espèces animales. C. R. Soc. Biol. (Paris) 1927, 96, 1124.

26. Broman, T. Weitere Untersuchungen über die Farbindikatormethode als Funktionsprobe der Bluthirnschranke (BHS) im Tierexperiment. Acta physiol. scand. 1941, 2, 83.

27. Fries, B. A., and Chaikoff, I. L. The phosphorus metabolism of the brain as measured with radioactive phosphorus. J. biol. Chem. 1941, 141, 479.

28. Bakay, L. Studies on blood-brain barrier with radioactive phosphorus. Arch. Neurol. Psychiat. 1953, 70, 30.

29. Katzman, R., and Leiderman, P. H. Brain potassium exchange in normal adult and immature rats. Amer. J. Physiol. 1953, 175, 263.

30. Ernster, L., Herlin, L., and Zetterström, R. Experimental studies on the pathogenesis of kernicterus. Pediatrics 1957, 20, 647. 
31. Driscoll, S., and Hsia, D. Y. Y. Immaturity of enzyme systems during early infancy. Pediatrics. In press.

32. Schmid, R. Direct-reacting bilirubin, bilirubin glucuronide, in serum, bile, and urine. Science 1956, 124, 76.

33. Klatskin, G., and Bungards, L. Bilirubin-protein linkages in serum and their relationship to the van den Bergh reaction. J. clin. Invest. 1956, 35, 537.

34. Mollison, P. L., and Cutbush, M. Method of measuring severity of series of cases of hemolytic disease of newborn. Blood 1951, 6, 777.

35. Hsia, D. Y. Y., Allen, F. H., Jr., Gellis, S. S., and Diamond, L. K. Erythroblastosis fetalis. VIII. Studies of serum bilirubin in relation to kernicterus. New Engl. J. Med. 1952, 247, 668.

36. Zuelzer, W. W., and Mudgett, R. T. Kernicterus : Etiologic study based on an analysis of 55 cases. Pediatrics 1950, 6, 452.
37. Arey, J. B., and Dent, J. Pathologic findings in premature infants. Amer. J. clin. Path. 1950, 20, 1016.

38. Aidin, R., Corner, B., and Tovey, G. Kernicterus and prematurity. Lancet 1950, 1, 1153.

39. Claireaux, A. E., Cole, P. G., and Lathe, G. H. Icterus of the brain in the newborn. Lancet 1953, 2, 1226.

40. Govan, A. D. T., and Scott, J. M. Kernicterus and prematurity. Lancet 1953, 1, 611.

41. Black-Schaffer, B., Krambe, S., Furuta, M., and Moloney, W. C. Neonatal jaundice and kernicterus. Amer. J. Dis. Child. 1954, 87, 737.

42. Crosse, V. M., Meyer, T. C., and Gerrard, J. W. Kernicterus and prematurity. Arch. Dis. Childh. 1955, 30, 501.

43. Meyer, T. C. A study of serum bilirubin levels in relation to kernicterus and prematurity. Arch. Dis. Childh. 1956, 31, 75.

44. Vogel, F. S. Studies on the pathogenesis of kernicterus. J. exp. Med. 1953, 98, 509. 